Indonesian Journal of Biotechnology, June, 2014

Vol. 19, No. 1, pp.43-55

\title{
Expression analysis of antioxidant genes in response to drought stress in the flag leaf of two Indonesian rice cultivars
}

\author{
Refli $^{1,2^{*}}$, Sukarti Muljopawiro ${ }^{1}$, Kumala Dewi ${ }^{1}$ and Diah Rachmawati ${ }^{1}$
}

${ }^{1}$ Faculty of Biology, Universitas Gadjah Mada, Yogyakarta, Indonesia

${ }^{2}$ Faculty of Science and Engineering, Universitas Nusa Cendana, Kupang, Indonesia

\begin{abstract}
The objective of this study was to analysis the expression of antioxidant genes in response to drought stress in Indonesian rice. The malondialdehyde (MDA) content and the expression of $\mathrm{Cu}-\mathrm{ZnSod}{ }_{1}, \mathrm{cCu}-\mathrm{ZnSod}{ }_{2}$, $\mathrm{MnSod}_{1,}, \mathrm{CApx}_{a^{\prime}}, \mathrm{CApx}_{b^{\prime}}$ chl-sApx, Cat ${ }_{1,} \mathrm{Cat}_{2,} \mathrm{Cat}_{3^{\prime}} \mathrm{Gr}_{1^{\prime}} \mathrm{Gr}_{2^{\prime}}$ and $\mathrm{Gr}_{3}$ genes were assayed in the rice flag leaf of Ciherang and Situ Bagendit cultivars subjected to control, mild and severe drought during the grain filling phase. Increase in MDA content of Ciherang treated to mild and severe drought was almost two-fold and three-fold respectively, while MDA content in Situ Bagendit subjected to mild and severe drought increased approximately one-fold and two-fold as compared to the control. The semi quantitative reverse transcription polymerase chain reaction (sqRT-PCR) analysis showed that the expression of $c \mathrm{Cu}-\mathrm{ZnSod}{ }_{1} \mathrm{MnSod}_{1^{\prime}} \mathrm{Cat}_{2^{\prime}} \mathrm{Gr}_{3}$ genes of Ciherang, and $c \mathrm{Cu}$-ZnSod ${ }_{2^{\prime}} \mathrm{MnSod}_{1^{\prime}} c A p x_{\alpha^{\prime}} c A p x_{b^{\prime}} c h l-s A P X, \mathrm{Cat}_{2}$ and $\mathrm{Gr}_{1}$ genes of Situ Bagendit increased in flag leaf of plant treated to drought. Expressions of $c A p x_{b^{\prime}}$ chl-sApx, Cat ${ }_{3}$ of Ciherang and $\mathrm{Cu}-\mathrm{ZnSod}{ }_{1}$ and $\mathrm{Gr}_{2}$ genes of Situ Bagendit were not changed significantly by drought stress. Decreased expression was shown by $c \mathrm{Cu}-\mathrm{ZnSod}{ }_{2^{\prime}}, \mathrm{Apx} x_{a^{\prime}} \mathrm{Cat}_{1^{\prime}} \mathrm{Gr}_{1}$ and $\mathrm{Gr}_{2}$ genes of Ciherang, and Cat ${ }_{1} \mathrm{Cat}_{3}$ and $\mathrm{Gr}_{3}$ genes of Situ Bagendit. The results indicated that the activity of oxidative defense was regulated by four genes; $c \mathrm{Cu}$-ZnSod ${ }_{1}, \mathrm{MnSod}_{1}$, $\mathrm{Cat}_{2^{\prime}}$ $\mathrm{Gr}_{3}$ in Ciherang, and eight genes; $c \mathrm{Cu}-\mathrm{ZnSod}{ }_{1^{\prime}} c \mathrm{Cu}-\mathrm{ZnSod}_{2^{\prime}} \mathrm{MnSod}_{1^{\prime}} c A p x_{a^{\prime}} c A p x_{b^{\prime}}$ chl-sApx, Cat ${ }_{2}$ and Gr ${ }_{1}$ in Situ Bagendit. Therefore, differences in the number of antioxidant genes controlling oxidative defense system might determine the difference of the oxidative defense capacity between both cultivars in response to drought stress during grain filling.
\end{abstract}

Keywords: rice, leaf flag, drought, lipid peroxidation, antioxidant genes, sqRT-PCR

\section{Introduction}

Drought stimulated the formation of reactive oxygen species (ROS) such as superoxide $\left(\mathrm{O}_{2}{ }^{*}-\right)$, hydrogen peroxide $\left(\mathrm{H}_{2} \mathrm{O}_{2}\right)$ and hydroxyl radical $\left(\mathrm{OH}^{*}\right)$. Being highly reactive, the presence of excessive ROS could damage cellular components such as lipid, protein, nucleic acid and enzyme (Ahmad et al., 2008), which was called oxidative stress. The level of oxidative stress in plant could

\section{*Corresponding author:}

Refli

Faculty of Biology, Universitas Gadjah Mada, Yogyakarta 55281, Indonesia. Tel: 62-274-580-839. E-mail: refli@mail.ugm.ac.id/refliundana@gmail. com be determined by quantifying the content of melanoaldehyde (MDA) as indicator of lipid peroxidation. Plant, therefore, protected their cells from oxidative stress by generating oxidative self-defense systems consisting of antioxidant molecules such as ascorbic acid (AsA), alpha tocopherol (a-Toc), and glutathione as well as antioxidant enzymes e.g. superoxide dismutase (SOD), ascorbate peroxidase (APX), catalase (CAT), and glutathione reductase (GR) (Apel and Hirt, 2004). The SOD enzyme catalyzed the conversion of superdioxide radical $\left(\mathrm{O}_{2}{ }^{*}\right)$ into $\mathrm{H}_{2} \mathrm{O}_{2}$, while the APX and CAT enzymes catalyzed the alteration of $\mathrm{H}_{2} \mathrm{O}_{2}$ into $\mathrm{O}_{2}$ and $\mathrm{H}_{2} \mathrm{O}$. The GR catalyzed the production of reduced glutathione (GSH) that was 
required as a substrate for AsA synthesis in the ascorbate-glutathione cycle. Both AsA and GSH could directly detoxify $\mathrm{O}_{2}{ }^{*}$ - radical and thus contribute to non-enzymatic ROS scavenging.

Rice (Oryza sativa L) as a staple food for more than half of the world's population and providing $50-80 \%$ of their daily calorie intake (Khush, 2005) was adversely affected by drought. Fukai et al. (1999) stated that drought was the primary cause of rice yield lost among the abiotic stresses. The loss of rice yield due to drought was 1335\% (Khunthasuvon et al., 1998; Fukai et al., 1999). Selote and Khana-Copra (2004) found that seed formation in the drought stressed plants was significantly reduced as compared to the unstressed rice plants of the N22 and N188 cultivars. The failure of microsporogenesis caused by droughtinduced oxidative stress has also been reported in the rice of N31 cultivars (Nguyen and Sutton, 2009). Therefore, the yield loss under drought stress seemed to be associated with reducing the efficiency of self-oxidative defense to eliminate ROS activity (Selote and Khana-Copra, 2004).

Reduction in the oxidative defense system appears to be regulated by the expression level of antioxidant genes. This has been studied extensively using transgenic plants subjected to various abiotic stresses. Transgenic species transformed with Sod genes showed an increase in the expression of genes associated with tolerance to the abiotic stresses (Murgia et al., 2004; Tang et al., 2006; Prashanth et al., 2008). Other studies reported that transgenic rice containing $\mathrm{Cu}-\mathrm{ZnSod}_{1}$ gene isolated from other species showed better tolerance to drought, salinity or methyl viologen induced-oxidative stress than untransgenic control plants (Wang et al., 2010, Sarangi et al., 2011). Moreover, enhanced oxidative defense in rice and tobacco plants applied to abiotic stress could be achieved through Apx overexpression (Sun et al., 2010; Sato et al., 2011). Overexpression of Cat gene also induced increasing oxidative defense in cabbage plants to reduce ROS damage stimulated by salinity stress (Tseng et al., 2007). The higher tolerance to oxidative stress was observed in tobacco plant transformed with $\mathrm{Gr}$ gene isolated from E. coli (Aono et al,. 1991).

The studies of the oxidative defense mechanism in plant including rice have been reported extensively and it has been suggested that different expression of an antioxidant gene(s) and the activity of an antioxidant enzyme(s) determined the capability of plant to cope with oxidative stress. However, most of those studies only emphasized on the defense system in the pre-anthesis phase. The oxidative defense mechanism that involves antioxidant genes on the flag leaf of Indonesian rice cultivars during postanthesis i.e. grain filling phase remained poorly understood. To address this issue, a study was performed on the expression of antioxidant genes in the Indonesian rice flag leaf of Ciherang (susceptible to drought) and Situ Bagendit (tolerant to drought) cultivars subjected to different drought stress based on the fraction of the transpirable soil water. The objective of the present study was to analyze the effects of drought stress on lipid peroxidation and the expression of antioxidant genes in the flag leaf of Ciherang and Situ Bagendit cultivars.

\section{Materials and Methods \\ Plant material and Growth condition}

Seeds of indica rice of Ciherang and Situ Bagendit cultivars were sterilized with $10 \%$ sodium hypochlorite for a minute and washed extensively using distilled water. Then seeds were imbibed in distilled water for 12 hours at dark condition. The imbibed seeds were germinated in petri dishes containing two sheets of the moistened filter paper at $30^{\circ} \mathrm{C}$ in the dark room for 5 days. Uniformly germinated seeds were selected and planted in a plastic box (40 $\mathrm{cm}$ in length $\times 25 \mathrm{~cm}$ in width $\times 15 \mathrm{~cm}$ in height) containing a mixture of clay and sand $(2: 1, \mathrm{v} / \mathrm{v})$. The germinated seeds were 
grown under natural light at $30^{\circ} \mathrm{C}$ day and $25^{\circ} \mathrm{C}$ night in a glasshouse. Twenty-days old seedlings were selected and cultivated in the polyethylene polybag filled with $7 \mathrm{~kg}$ of a clay-sand-compost mixture $(2: 1: 1 \mathrm{v} / \mathrm{v})$. Seedlings were grown in a natural controlled glasshouse.

\section{Application of drought treatment}

Drought treatments were based on the fraction of transpirable soil water (FTSW) (Sinclair and Ludlow, 1986) with three replications. Drought stress was imposed by initiating a soil dry-down protocol starting three days before anthesis. The dry-down process continued until the pot reached the target of FTSW. The drought treatments were started on the seventh day and ended on the twentieth day after the initial anthesis The drought treatments consisted of FTSW 1.0 (control or well-watered), FTSW 0.5 (mild drought) and FTSW 0.2 (severe drought) (He et al., 2009; Sharoni et al., 2012). The FTSW was maintained gravimetrically in all of the polybag during the treatment.

\section{Estimation of lipid peroxidation}

Lipid peroxidation was estimated as malonyaldehyde (MDA) content. Two hundred and fifty mg of the frozen flag leaf was crushed to powder and homogenized in $5 \mathrm{ml} 0.1 \%(\mathrm{w} / \mathrm{v})$ trichchloroacetic acid solution. The sample was then centrifuged at $15,000 \mathrm{rpm}, 4^{\circ} \mathrm{C}$ for $20 \mathrm{~min}$. One $\mathrm{ml}$ of the supernatant was pipetted into the test tube and added $4 \mathrm{ml} 0.5 \%$ thiobarbituric acid in $20 \%$ trichchloroacetic acid. The test tube was heated at a temperature of $95^{\circ} \mathrm{C}$ in the waterbath for 30 minutes, and then cooled in an ice block. The mixture was centrifuged at $15,000 \mathrm{rpm}, 4^{\circ} \mathrm{C}$ for 20 minutes. The supernatant was removed and absorption value of each supernatant was read at 450, 532 and $600 \mathrm{~nm}$. Blank solution was $0.5 \%$ thiobarbituric acid in $20 \%$ trichchloroacetic acid solution. The MDA content was calculated using equation developed by Gao (2000).

\section{RNA extraction and cDNA synthesis}

Rice flag leaf at grain filling stage was harvested at seven days after application of drought treatment. The leaf was immediately frozen at $-80^{\circ} \mathrm{C}$, prior to the isolation of RNA. Total RNA was isolated using the RNeasy ${ }^{\circledR}$ Plant Mini Kit (Qiagen, Germany) according to the manufacturer's instructions. The isolated RNA was quantified by Nano Drop Spectrophotometer. The first-strand cDNA was synthesized using SuperScript II firststrand synthesis system (Invitrogen, CA, USA) and oligo-dT ${ }_{18}$ (Invitrogen, CA, USA) as per manufacturer's instruction then stored at $-20^{\circ} \mathrm{C}$ for further used.

\section{Semi-quantitative RT PCR assay}

To determine the expression profile of the rice antioxidant genes, semi-quantitative reverse transcription-polymerase chain reaction (sq-RT-PCR) assay was conducted using the published specific primer sequences (Kim et al., 2004; Hong et al., 2009; Chou et al., 2012). The primers used in this research were: $\mathrm{Cu}-\mathrm{ZnSod}-\mathrm{F}$ (GAGATTCCAAACCAGCAGGA), Cu$\mathrm{ZnSod}_{1}$-R (TTGTAGTGTGGCCCAG TTGA), $c \mathrm{Cu}-\mathrm{Zn} \mathrm{Sod}_{2}-\mathrm{F}$ (ACAGCCAGATCCCCCTT ACT), $c C u-Z n S o d$ - $R$ (GCAAACTGCACACT GGTCAT), $\mathrm{MnSod}_{1}-\mathrm{F}$ (GGAGGCCATGTCA ATCATTC) $M n S o d_{1}-R$ (CACAAGGTCCAGA AGTGCAA), $c A P X_{a^{\prime}}-F$ (GTTTTGAGGGA CCTTGGACA), $c A P X_{a^{\prime}} R$ (TAACAGCCCA CCGAGACATT), $c A P X_{b}-F$ (TCTTCCT GATGCCACACAAG), $c A P X_{b}-R($ GTCCTCAT CCGCAGCATATT), chl-sAPX-F (CAATTG AGGAAGCTGGTGGT), $c h l-s A P X-R$ (ACTTCAGCGATCTGGCTCAT), Cat ${ }_{1}-F$ (CCACCACAACAACCACTACG), $\mathrm{Cat}_{1}-\mathrm{R}$ (CCAACGACTCATCACACTGG), Cat $5^{\prime \prime}$-F (CCAACAGGCTGGTGAGAGAT), $\mathrm{Cat}_{2}-\mathrm{R}$ (ATTCACGACTACGGCTGGTC), $\mathrm{Cat}_{3}-\mathrm{F}$ (ACCGGTTCATCAAGAGATGG), $\mathrm{Cat}_{3}-\mathrm{R}$ (ACACGAATTGTGCGGTGATA), Gr $r_{1}-F$ (TCTCAGAGGGACTTCTCTACT), $G r_{1}-R$ (AGGCAGTGGTACTCACATGGT), $G r_{2}-F$ (GTGTACTCTGGTTTGCATCT), $G r_{2}-R$ (CTGCAGGCAGAACGAATGAT), $\mathrm{Gr}_{3}-F$ 
(CAACAGACAGATATCGGTA), $G r_{3}-R$ (TACTATCAACATCCTGAAGC)- OsAct-F (ATGCTCTCCCCCATGCTATC), and OsAct-R (TCTTCCTTGCTCATCCTGTC). The amplification reaction mixture consisted of $2 \mu \mathrm{l}$ 10X PCR buffer minus $\mathrm{Mg}^{2+}, 2 \mu \mathrm{l} 10$ mM dNTP mix, $0.2 \mu 1$ Taq DNA polymerase (5 units $/ \mu \mathrm{l})$ (Invitrogen, CA, USA), $1 \mu \mathrm{l} 10$ $\mu \mathrm{M}$ forward primer, $1 \mu \mathrm{l} 10 \mu \mathrm{M}$ reverse primer, $12.8 \mu \mathrm{l}{ }^{\mathrm{dd}} \mathrm{H}_{2} \mathrm{O}$, and $1 \mu \mathrm{l}$ cDNA. The PCR was performed using a Mastercycler Personal Thermocycler (Eppendorf). For all PCR programs, the reaction mixtures were initially denatured at $94^{\circ} \mathrm{C}$ for $5 \mathrm{~min}$, followed by 30-35 cycles of denaturation at $94^{\circ} \mathrm{C}$ for $45 \mathrm{sec}$, annealing at $56-58^{\circ} \mathrm{C}$ for 45 $\mathrm{sec}$, and extension at $72^{\circ} \mathrm{C}$ for $1,5 \mathrm{~min}$. The final extension was performed at $72^{\circ} \mathrm{C}$ for $10 \mathrm{~min}$. For all treatments, three replicates of RT-PCR analysis were conducted.

For each sample, $5 \mu \mathrm{L}$ PCR products were added with $1 \mathrm{~mL}$ loading dye (Promega), electrophoresed in a $1 \%$ syberseen (Promega)agarose gels buffered with $1 X$ Tris-BoricEDTA (1X TBE), and visualized under UV light. The images were recorded using a digital camera (Cannon). ImageJ analyzer software was used to quantify the PCR band intensities for evaluating the gene expression level.

\section{Results and discussion Lipid peroxidation}

Reactive oxygen species generated under drought or other stress leads to the oxidation of unsaturated fatty acids in cell membranes to yield MDA (Behnamnia et al., 2009). The content of MDA as indicator for the occurrence of oxidative stress was also determined within experiment to evaluate the negative impact of the drought-induced oxidative stress in the rice flag leaf of Ciherang and Situ Bagendit cultivars. Both cultivars showed a similar trend in MDA content in their flag leaf in response to drought stress, however an increase in the MDA content of Ciherang flag leaf was higher than that of Situ Bagendit flag leaf (Figure 1). Mild and severe drought stress increased almost two-fold and three-fold of the MDA content of the Ciherang flag leaf, and one-fold and two-fold in that of Situ Bagendit flag leaf as compared to their control. The different increase in MDA content of the plants caused by abiotic stress have been reported by previous studies (Basu, 2010; Damanik et al., 2010; Wu, et al., 2012). The difference of the MDA content between Ciherang and Situ Bagendit cultivars induced by drought stress indicated that there was difference in the intensity of cell impairment caused by ROS activity. Drought stress trigger the formation

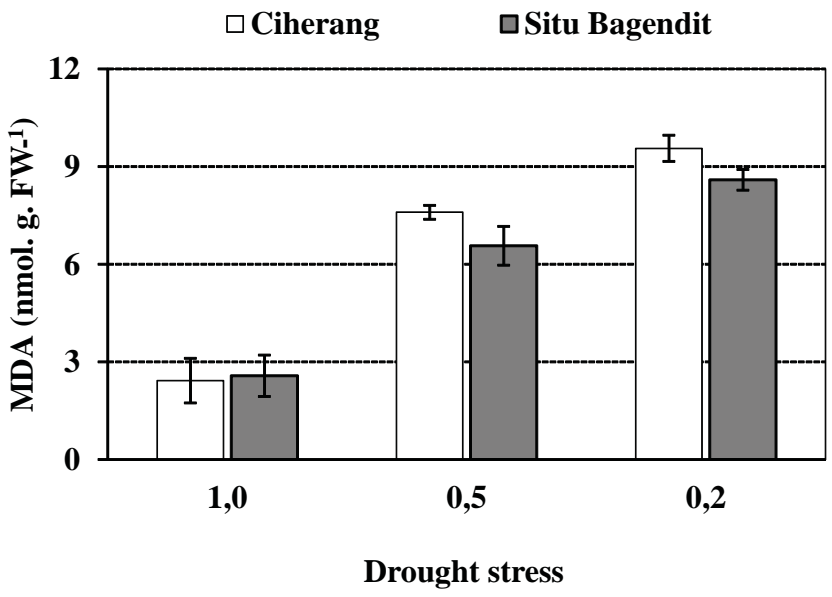

Figure 1. The effect of drought stress on the content of malonyaldehyde (MDA) in the flag leaf of Ciherang and Situ Bagendit cultivars. Error bars indicate the SD $(n=3)$. 
of the $\mathrm{O}_{2}{ }^{-*}$ and $\mathrm{H}_{2} \mathrm{O}_{2}$, radicals which could directly attack the membrane lipid (Mittler et al., 2004). Increase in $\mathrm{H}_{2} \mathrm{O}_{2}$ levels in rice treated to drougth and chilling caused lipid peroxidation folowed by enhacement of MDA level (Nguyen et al., 2009; Sato et al., 2011). Increase in lipid peroxidation (MDA) ascribe to decline in the antioxidant system enzyme activities (Fu et al., 2011).

This result indicated that the flag leaf of Ciherang cultivar possessed a less capacity of the antioxidative defense mechanism as compared to that of Situ Bagendit. Therefore, it was suggested that the level of oxidative damages by ROS activity relied on the antioxidative defense system of each cultivar during the stress. The regulation of antioxidant gene expression seems to be a key of regulation of the defense mechanism of the flag leaf of both cultivars.

\section{Antioxidant gene expression}

Gene expression in response to abiotic stress is usually studied at the level of steady- state mRNA abundance because it gives a more precise estimation of antioxidant gene activation than enzyme activity (Hong et al., 2009). As revealed in that study, drought stress stimulated the alteration in antioxidant gene expression. The present study was attempted to explore more deeply the oxidative defense mechanism through gene regulation in the flag leaf of Ciherang and Situ Bagendit cultivars in response to drought stress

\section{Sod genes}

Both Ciherang and Situ Bagendit cultivars exhibited a similar pattern of $\mathrm{Cu}$ $\mathrm{ZnSod}_{1}$ gene expression in their flag leaf in response to drought stress (Figure 2 and $3 \mathrm{~A}$ ). The expression of $\mathrm{Cu}-\mathrm{ZnSod}$ gene in the flag leaf of Ciherang and Situ Bagendit increased to 33.3 and 39.7 in mild drought, and 12.1 and $6.3 \%$ in severe drought, respectively, when compared with the control. Unlike $c \mathrm{Cu}-\mathrm{ZnSod}{ }_{1}$, the $c \mathrm{Cu}-\mathrm{ZnSod}{ }_{2}$ in the flag leaf of both cultivars showed a different expression

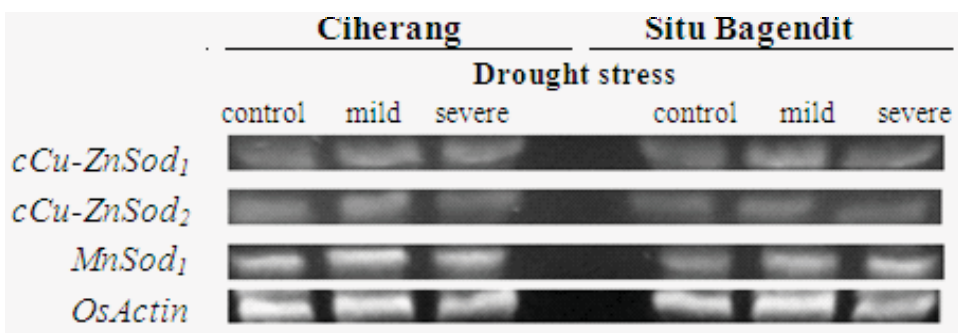

Figure 2. Expression profile of three Sod genes and OsActin in the flag leaf of Ciherang and Situ Bagendit cultivars treated to drought stress.
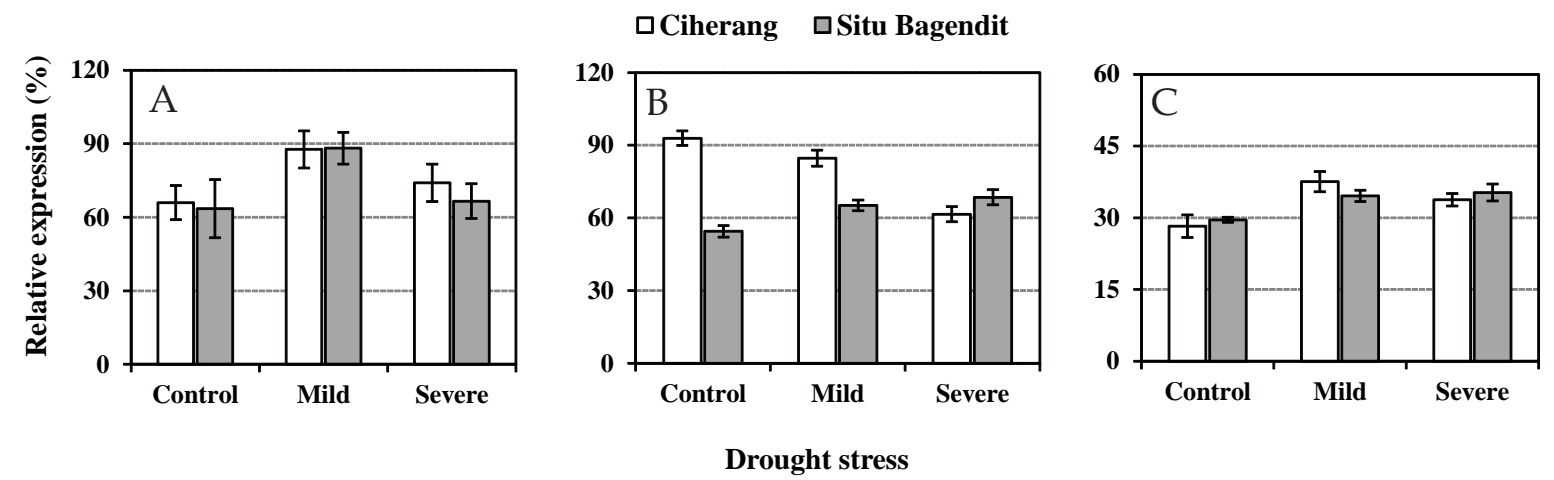

Figure 3. The effect of drought stress on the relative expression of Sod genes in the flag leaf of Ciherang and Situ Bagendit cultivars. A. $c \mathrm{Cu}-\mathrm{ZnSod}$, B. $c \mathrm{Cu}-\mathrm{ZnSod}_{2}$, C. $\mathrm{MnSod}_{1}$. Error bars indicate the SD (n=3) 
in response to an increase in drought stress (Figure 3B). The $\mathrm{cCu}-\mathrm{ZnSod}$, gene expression in the flag leaf of Ciherang decreased in mild $(9.7 \%)$ and severe $(33.3 \%)$ as compared to the control. Whereas the $c \mathrm{Cu}$-ZnSod 2 gene expression in the flag leaf of Situ Bagendit increased to 18.2 and $25.4 \%$ in mild and severe drought, respectively, as compared to the control. Figure 3C shows that the expression of $\mathrm{MnSod}_{1}$ gene was increased in the flag leaf of both cultivars with increase in drought stress. The flag leaf of Ciherang and Situ Bagendit had 21.4 and 13.3\% higher $\mathrm{MnSod}_{1}$ expression, respectively, under mild drought than their control. The $\mathrm{MnSod}_{1}$ expression in the flag leaf was higher in Ciherang (35\%) and Situ Bagendit (16.7\%) under severe drought as compared to that of their control. The result indicated that the highest involvement of the $c \mathrm{Cu}-\mathrm{ZnSod}$ gene for supporting the oxidative defense of the flag leaf of both cultivars only took place in mild stress.

Decrease in $\mathrm{cCu}-\mathrm{ZnSod}$ gene expression in the flag leaf of Ciherang indicated that the gene might not involve in controlling the activity of SOD enzyme for scavenging $\mathrm{O}_{2}{ }^{*}$ radical during the drought stress. The present study indicated that $\mathrm{c} \mathrm{Cu}-\mathrm{ZnSod}$, gene involved in the regulation of the oxidative defense mechanism in the flag leaf of Situ Bagendit only. The defense mechanism in the flag leaf of both cultivars involved the regulation of $\mathrm{MnSod}_{1}$ gene. The $\mathrm{MnSod}_{1}$ gene played a crucial role for controlling the free radical destruction via increasing the catalytic activity of SOD enzyme in the flag leaf of Situ Bagendit. It could be inferred that the capacity of oxidative defense in scavenging superoxide radical was less effectively in the flag leaf of Ciherang than Situ Bagendit. The different capacity could also affect the level of the plant tolerance to drought stress. It is associated with the change of SOD enzyme activity to protect cells against oxidative stress caused by the deleterious activity of $\mathrm{O}_{2}{ }^{*}$ - radical ( $\mathrm{Fu}$ et al., 2010). Tayal et al. (2004) stated that the gene expression in response to oxidative stress was regulated by the transcription factor(s). Transcription factors e.g. $D R E B, H D G_{11}$ and $N A C$ became a regulator of expression genes involving in drought tolerance of rice $(\mathrm{Oh}$ et al., 2005; Hu et al., 2006; Yu et al.,2008). It seemed that transcription factors could involve the oxidative defense system via the regulation of the antioxidant gene expression in response to drought.

\section{Apx genes}

Drought stress stimulated a different expression of $A p x$ gene in the flag leaf of Ciherang and Situ Bagendit cultivars (Figure 4). The Apx $x_{a}$ expression in the flag leaf of Ciherang was down regulated but that in the flag leaf of Situ Bagendit was up-regulated in response to an increase in the level of drought stress (Figure 5A). The $c A p x_{a}$ expression in the flag leaf of Ciherang decreased to 13.9 and $47.7 \%$ in mild and severe drought, respectively, as compared to the control. In contrast, the expression level of $c A p x$ gene in the flag leaf of Situ Bagendit increased to $94.1 \%$ in mild drought and $155.9 \%$ in severe drought as compared with the control. Moreover, the expression of $c A p x_{b}$ in the flag leaf of Ciherang enhanced in the mild drought $(7.7 \%)$, but did not change significantly in severe drought $(1.1 \%)$ as compared with the expression level of that gene in control. The increase of $c A p x_{b}$ expression level occured in the flag leaf of Situ Bagendit concomitant with increase in the level of drought stress (Figure 5B). The $c A p x_{b}$ expression level increased by $23.2 \%$ in mild drought and $46.3 \%$ in severe drought compared to the control. Figure $5 \mathrm{C}$ shows that the higher expression of chl-sApx in the flag leaf of Ciherang under mild (58\%) and severed $(16.6 \%)$ drought than that of the control. The expression of chl-sApx in the flag leaf of Situ Bagendit enhanced to 400 and $480 \%$ in both mild and severe drought as compared to the control.

The results indicated that the degradation of $\mathrm{H}_{2} \mathrm{O}_{2}$ into $\mathrm{H}_{2} \mathrm{O}$ and $\mathrm{O}_{2}$ by 


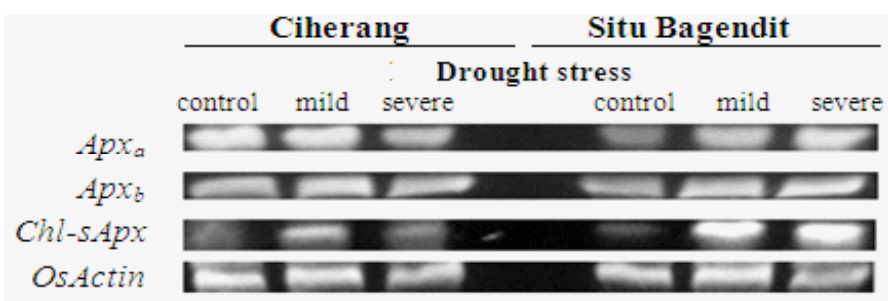

Figure 4. Expression profile of three Apx genes and OsActin in the flag leaf of Ciherang and Situ Bagendit cultivars treated to drought stress.
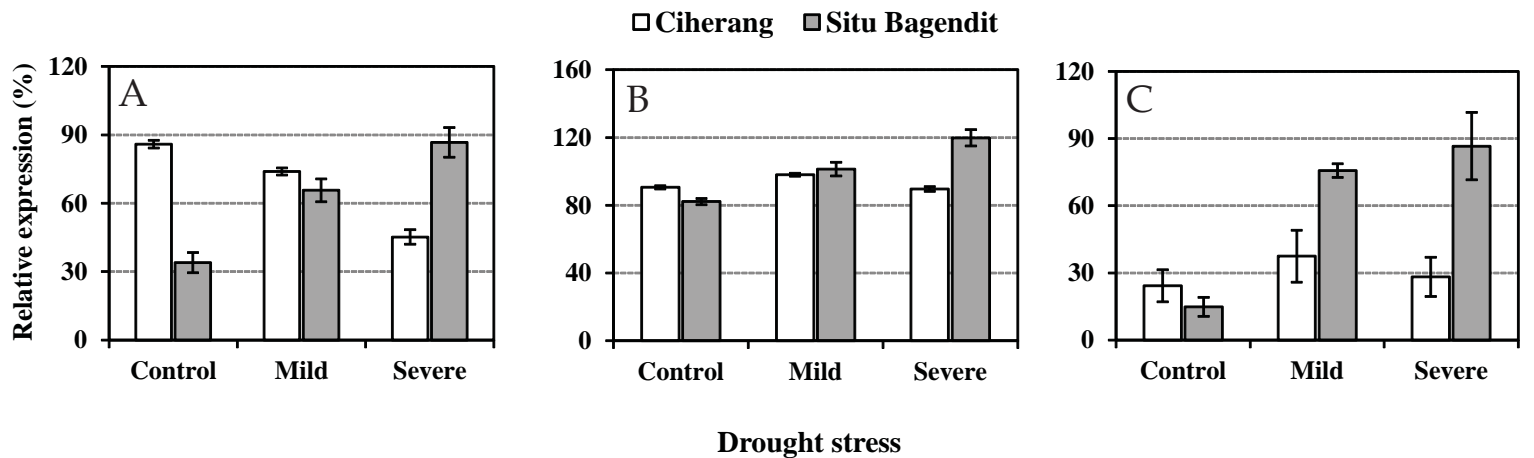

Figure 5. The effect of drought stress on the relative expression of Apx genes in the flag leaf of Ciherang and Situ Bagendit cultivars. A. $c A p x_{a^{\prime}}$ B. $c A p x_{b^{\prime}}$ C. chl-sApx. Error bars indicate the SD (n=3).

APX enzyme in the flag leaf of Ciherang under mild drought involved the regulation of $c A p x_{b}$ and chl-sApx genes. But a slight decrease in function of both genes to regulate $\mathrm{H}_{2} \mathrm{O}_{2}$ scavenging enzyme exhibited in the flag leaf of Ciherang treated to severed drought. The function of the APX enzyme in flag leaf of Situ the was regulated by three Apx genes. The previous studies found that the activity of APX enzyme in the leaf of rice plant treated to abiotic stress may be associated with the expression of Apx genes (Sato et al., 2011; Chou et al., 2012). Therefore, the Apx genes played a major role in the defense system of Situ Bagendit were chl-sApx, $c A p x_{b}$ then $c A p x_{a}$.

The variation of relative Apx expression in the flag leaf indicated the differences of the oxidative defense system between both cultivars. These findings were well supported by previous studies on pea (Mittler and Zilinskas, 1994), Arabidopsis (Conklin and Last, 1995), rice (Morita et al., 1999), spinach (Yoshimura et al., 2000), and potato (Kawakami et al., 2002). Eight
Apx genes in rice showed the different level of their expression in response to abiotic stress (Teixeira et al., 2006). The expression of $c A p x_{a}$ was lower than that of $c A p x_{b}$ in the leaf of rice seedlings in response to salinity stress (Menezes-Benavente et al., 2004). The overexpression of $c A p x_{b}$ increased the tolerance of transgenic Arabidopsis plants against salinity stress (Lu et al., 2007). Taken together, these present study suggested that the role of each Apx gene in the oxidative defense of plants under abiotic stress depend on the kind of cultivar, organ, growth phase and stress. The study also suggested that the function of oxidative defense for scavenging $\mathrm{H}_{2} \mathrm{O}_{2}$ radical in the flag leaf of Situ Bagendit was more effectively than that of Ciherang in accordance with an elevation of the expression of the Apx genes.

\section{Cat genes}

Together with APX, CAT enzyme plays an important role in the scavenging of hydrogen peroxide within cells. The activity of CAT enzyme was controlled by the Cat 
genes. The Cat expression was shown in Figure 6. The Cat ${ }_{1}$ expression profile in the flag leaf of the Ciherang and Situ Bagendit cultivars had a similar pattern in response to drought stress (Figure 7A). The Cat expression levels in the flag leaf of both cultivars either treated to mild or severe drought was lower than that of the control The decrease of the Cat ${ }_{1}$ expression in the flag leaf of Ciherang and Situ Bagendit cultivars were 48.7 and $41.8 \%$ under mild drought, and 52.9 and $23.1 \%$ under severe drought, respectively, as compared to their controls. The lower expression of the Cat ${ }_{2}$ gene was detected in the flag leaf of the control of Ciherang and Situ Bagendit as compared to the both cultivars treated to either mild or severe drought stress (Figure 7B). However, there was no a substantial difference in the $\mathrm{Cat}_{2}$ expression between cultivars when the plants were subjected to either mild or severe drought. The Cat ${ }_{2}$ expression in the flag leaf of Ciherang enhanced to 92 and $76 \%$ under mild and severe drought compared to the control. In the leaf of Situ Bagendit the Cat, expression showed an increase by 33.3 and
$27.8 \%$ under mild and severe drought in comparison with the control.

Figure 7C shows that the different drought level could not induce significantly the distinction of $\mathrm{Cat}_{3}$ expression in Ciherang plants. The Cat ${ }_{3}$ expression level was reduced by either mild or severe drought stress as detected in the flag leaf of Situ Bagendit as compared to the control. The Cat Caxpression $_{3}$ in the flag leaf of Ciherang was 10.5 and $5.3 \%$ higher under mild and severe drought, respectively, than the control. Whereas in the flag leaf of Situ Bagendit under mild and severe drought the Cat gene showed a $21.9 \%$ decrease in its expression as compared to that of the control. The present study indicated that the $\mathrm{H}_{2} \mathrm{O}_{2}$ degradation in the flag leaf of both cultivars only involved the regulation of $\mathrm{Cat}_{2}$ gene. A previous study observed that expression of $\mathrm{Cat}_{1} \mathrm{Cat}_{2}$ and $\mathrm{Cat}_{3}$ genes increased in leaves of the ABAtreated maize seedling (Scandalios, 2005). Study on Arabidopsis found that ABA induced an increase in Cat ${ }_{1}$ expression (Xing et al., 2008). The expression of Cat ${ }_{2}$ and $\mathrm{Cat}_{3}$ also increased under salinity (Yamane et al.,

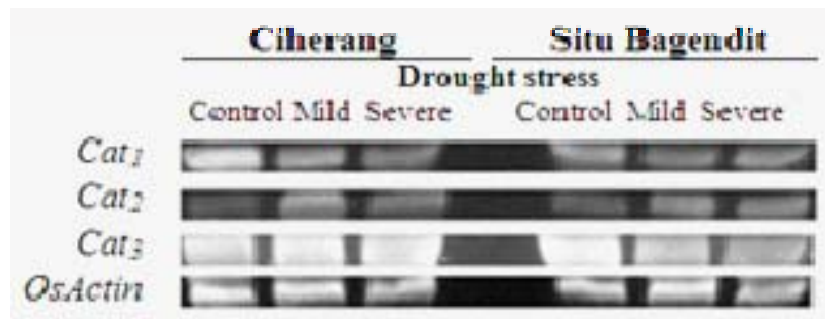

Figure 6. Expression profile of three Cat genes and OsActin in the flag leaf of Ciherang and Situ Bagendit cultivars treated to drought stress.
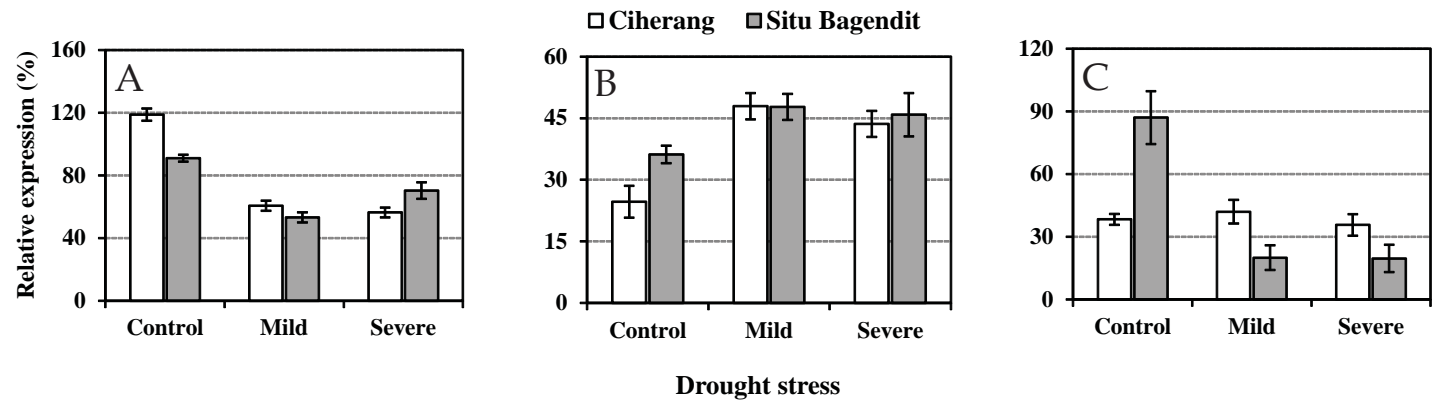

Figure 7. The effect of drought stress on the relative expression of Cat genes in the flag leaf of Ciherang and Situ Bagendit cultivars. A. Cat $t_{1}$ B. Cat ${ }_{2}$ C. Cat . Error bars indicate the SD (n=3) 


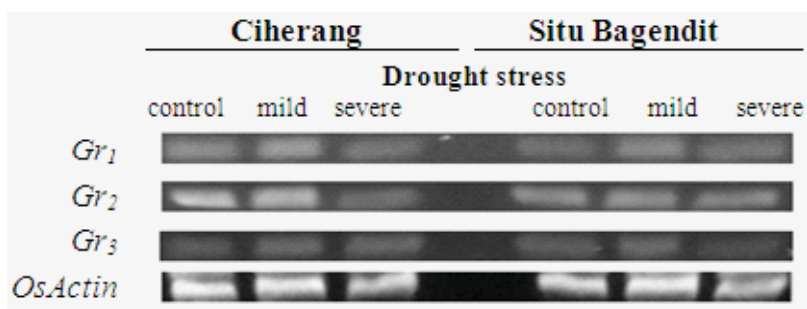

Figure 8. Expression profiles of three Gr genes and OsActin in the flag leaf of Ciherang and Situ Bagendit cultivars treated to drought stress.
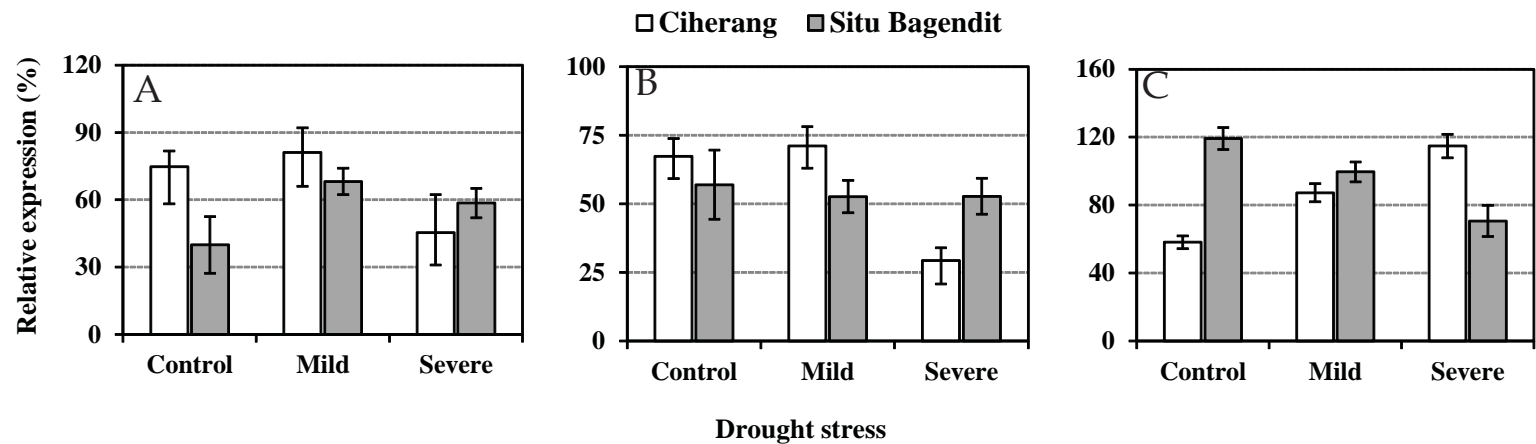

Figure 9. The effect of drought stress on the relative expression of $\mathrm{Gr}$ genes in the flag leaf of Ciherang and Situ Bagendit cultivars. A. $G r_{1}$, B. $G r_{2}$, C. Gr $r_{3}$. Error bars indicate the SD $(\mathrm{n}=3)$

2010). Therefore, the number of Cat genes for controlling oxidative defense system relied on the type of species and the level of abiotic stress.

\section{Gr genes}

The $G r_{1}$ expression showed a similar pattern in the flag leaf of both Ciherang and Situ Bagendit cultivars in response to drought (Figure 8). The $G r_{1}$ expression was higher in the flag leaf of Ciherang than that of Situ Bagendit when both cultivars were subjected to control and mild stress. But under severe drought the $G r_{1}$ expression of Ciherang was lower that of Situ Bagendit. The highest expression of $G r_{1}$ in both cultivars was noticed in mild drought stress (9A). The $\mathrm{Gr}_{1}$ expression in the flag leaf of Ciherang was slightly higher $(8 \%)$ in mild drought, but lower $(40 \%)$ in severe drought than that in the control. Meanwhile, in the flag leaf of Situ Bagendit, $\mathrm{Gr}_{1}$ expression increased to 70 and $47 \%$ in mild and severe drought, respectively, as compared to the control. The $\mathrm{Gr}_{2}$ expression in the flag leaf of Ciherang also enhanced to $6 \%$ in mild drought stress but reduced $56.7 \%$ in severe drought stress when compared to its control. There was not any substantial change in the $\mathrm{Gr}_{2}$ expression of Situ Bagendit flag leaf in response to increase in drought level (Figure 9B). Change in $\mathrm{Gr}_{3}$ expression level in the flag leaf exhibited a contradictory pattern between both cultivars in response to the drought stress (Figure 9C). In the flag leaf of Ciherang, the $\mathrm{Gr}_{3}$ expression was increased by 50 and $98.3 \%$ in mild and severe drought, respectively, as compared to the control. On the other hand, in the flag leaf of Situ Bagendit, the $\mathrm{Gr}_{3}$ expression was increased by $16 \%$ in mild drought, and $40.3 \%$ in severe drought, when compared to the control. The results indicated that the role of $\mathrm{Gr}_{1}$ for supporting the activity of the oxidative defense mechanism in the flag leaf of Ciherang acted maximally in mild drought stress only. However, the role of $G r_{1}$ declined in severe drought stress. The $G r_{1}$ role in the oxidative defense of the Situ Bagendit flag leaf enhanced with increase in drought stress. 
The study indicated that the function of $\mathrm{Gr}_{2}$ in the flag leaf of Ciherang was more effectively in mild drought stress but not in severe drought as compared with the control. Whereas, the $\mathrm{Gr}_{2}$ function in the flag leaf of Situ Bagendit remained stable even though the plants were subjected to mild and severe drought. This study suggested that the $G r_{1}$ and $G r_{2}$ genes did not engage the regulation of the oxidative defense system in the flag leaf of Ciherang under severe drought. The $G r_{3}$ gene appeared to be a regulator of the oxidative defense system via accelerating the catalytic activity of glutathione reductase enzyme in the Ciherang leaf under drought stress. This enzyme catalyzes the production of ascorbate acid through a glutathione-ascorbate acid cycle and protects cells against oxidative damage maintaining a high GSH/GSSG ratio (Foyer and Noctor, 2005; Chao et al., 2010). Because of the decrease in $\mathrm{Gr}_{3}$ expressions, it seems that this gene did not play a main role in the stress defense of the Situ Bagendit flag leaf. The activity of the GR enzyme in the defense system of Situ Bagendit was slightly and dominantly controlled by $\mathrm{Gr}_{2}$ and $G r_{1}$ gene, respectively. The different involvement of the $\mathrm{Gr}$ genes in the oxidative defense between both cultivars supported a previous study. Hong et al. (2009) found that the expression of $G r_{1}$ decreased but $G r_{2}$ and $\mathrm{Gr}_{3}$ increased in rice seedling treated to salinity and ABA. The different expression of $\mathrm{Gr}$ genes in plant under abiotic stress most likely due to the differential sensitivity to such stress. In addition, the different expression patterns in response to abiotic stress suggests that these genes have different physiological roles depend upon cultivars (Tsai et al., 2005).

\section{Conclusion}

Ciherang cultivar was more suffered under drought induced oxidative stress than Situ Bagendit cultivars based on the difference of lipid peroxidation (MDA levels) occurred within their flag leaf. Antioxidant gene expression in the flag leaf of Ciherang differed to that of Situ Bagendit in response to drought stress. The results showed that the activity of oxidative defense was regulated by four genes (cCu-ZnSod $\left.{ }_{1}, \mathrm{MnSod}_{1^{\prime}} \mathrm{Cat}_{2^{\prime}} \mathrm{Gr}_{3}\right)$ in the flag leaf of Ciherang, and eight genes (cCu-ZnSod $_{1^{\prime}}$ cCu-ZnSod, MnSod ${ }_{1^{\prime}}$ cApx ${ }_{a^{\prime}}$ $c A p x_{b^{\prime}}$ chl-sApx, Cat ${ }_{2}$ and $\left.G r_{1}\right)$ in the flag leaf of Situ Bagendit of the twelve antioxidant genes that were observed. The degradation of $\mathrm{O}_{2}{ }^{*}$ - radical into $\mathrm{H}_{2} \mathrm{O}_{2}$ catalized by SOD enzyme in the flag leaf under drought seemed to be controlled by $\mathrm{Cu}-\mathrm{ZnSod}{ }_{1}, \mathrm{MnSod}_{1}$ in Ciherang and $c \mathrm{Cu}-\mathrm{ZnSod}_{1^{\prime}} c \mathrm{Cu}-\mathrm{ZnSod}_{2^{\prime}} \mathrm{MnSod}_{1}$ in Situ Bagendit. Moreover, the elimination of destructive activity of $\mathrm{H}_{2} \mathrm{O}_{2}$ involved $\mathrm{Cat}_{2}$ in the flag leaf of Ciherang, and $c A p x_{a^{\prime}} c A p x_{b^{\prime}}$ chl$s A p x, C_{a t}$ in the flag leaf of Situ Bagendit. The ascorbate-glutathione cycle of the oxidative system in the flag leaf under severe drought involved $\mathrm{Gr}_{3}$ in Ciherang and $\mathrm{Gr}_{1}$ in Situ Bagendit. The data suggested that differences in the number of antioxidant genes controlling oxidative defense system might determine the difference of the oxidative defense capacity between both cultivars in response to drought stress during grain filling.

\section{Acknowledgements}

The authors are grateful to Indonesian Center for Rice Research (ICCR, Sukamandi, West Jawa, Indonesia) for provision of the rice seeds of Ciherang and Situ Bagendit cultivars. Technical support by Mrs. Alifah Mubaroka and plant growth maintenance by Mr. Ngatman are also gratefully acknowledged.

\section{References}

Ahmad, P., Sarwat, M., and Sharma, S. 2008. Reactive oxygen species, antioxidants and signaling in plants. J Plant Biol, 5, 167-173.

Apel, K., Hirt, H., 2004. Reactive oxygen species: metabolism, oxidative stress, and signal transduction. Annu. Rev Plant Biol, 55, 373-99.

Aono, M., Kubo, A., Saji, H., Natori, T., Tanaka, K., Kondo, N. 1991. Tolerance 
of active oxygen toxicity of transgenic Nicotiana tabacum that expresses the gene for glutathione reductase from Escherichia coli. Plant Cell Physiol, 32, 691-697.

Basu, S., Roychoundhury, A., Saha, P, P., Sengupta, D. N. 2010. Differential antioxidative responses of indica rice cultivars to drought stress. Plant Growth Regul, 60:51-59.

Behnamnia, M., Kalantari, Kh., M. and Rezanejad, F. 2009. Exogenous application of brassinosteroid alleviates droughtinduced oxidative stress in Lycopersicon esculentum L. Gener \& Apll. Plant Physiol, 5, 22-34.

Chao, Y.Y., Hong, C.Y., Kao, C.H. 2010. The decline in ascorbic acid content is associated with cadmium toxicity of rice seedlings. Plant Physiol. Bioch, 48:374381

Chou, T-S., Chao, Y-Y., Kao, C.H. 2012. Involvement of hydrogen peroxide in heat shock and cadmium-induced expression of ascorbate peroxidase and glutathione reductase in leaves of rice seedlings. J Plant Physiol, 169, 478-486.

Conklin, P.L., Last, R.L. 1995. Differential accumulation of mRNA in Arabidopsis thaliana exposed to ozone. Plant Physiol, 109, 203-212.

Damanik, R.I., Mahmood, M. Ismail, M.R., Ahmad, S., Zain, A.B. 2010. Responses of the antioxidative enzymes in Malaysian rice (Oryza sativa L.) cultivars under submergence condition. Acta Physiol Plant, 32, 739-747.

Foyer, C., Noctor, G. 2005. Oxidant and antioxidant signaling in plants: a reevaluation of the concept of oxidative stress in a physiological context. Plant Cell Environ, 28, 1056-1071.

Fu, G.F., Song, J., Li, Y.R., Yue, M.K., Xiong, J., Tao, L.X. 2010. Alteration of panicle antioxidant metabolisme and carbohydrate content and pistil water potential involved in spikelet sterility in rice under water-deficit stress. Rice Sci, 17, 303-310.
Fu, G.F., Song, J., Xiong, J., Li, Y.R., Chen, H.Z., LE M.K., Tao, L.X. 2011. Alteration of panicle antioxidant metabolisme and carbohydrate content and pistil water potential involved in spikelet sterility in rice under water-deficit stress. Rice Sci, 17, 303-310.

Fukai, S., Pantuwan, G., Jongdee, B., Cooper, M. 1999. Screening for drought tolerance in rainfed lowland rice. Field Crops Res, 64, 61-74.

Gao, J. F. (2000). Experiment Technique of Plant Physiology. Xiang, China. Xi'an World Books Press Company.

He, H., Serraj, R., Yang, Q. 2009. Changes in OsXTH gene expression, ABA content, and peduncle elongation in rice subjected to drought at the reproductive stage. Acta Physiol Plant, 31. 749-756.

Hong, C.W., Chao Y.Y., Yang, M.Y., Cho, S.C., Kao, C. H. 2009. Na+ but not Cl- or osmotic stress is involved in $\mathrm{NaCl}$-induced expression of Glutathione reductase in roots of rice seedlings. J Plant Physiol, 166, 1598-1606.

Hu, H.H., Dai, M.Q., Yao, J.L., Xiao, B.Z., Li, X.H., Zhang, Q.F, Xiong, L.Z. 2006. Overexpressing a NAM, ATAF, and CUC (NAC) transcription factor enhances drought tolerance and salt tolerance in rice. Proc Natl Acad Sci USA, 103, 12987-12992.

Kawakami, S., Matsumoto, Y., Matsunaga, A., Mayama, S., Mizuno, M. 2002. Molecular cloning of ascorbate peroxidase in potato tubers and its response during storage at low temperature. Plant Sci, 163, 829-836.

Khunthasuvon, S., Rajatasereekul, S., Hanviriyapant, P., Romyen, P., Fukai, S., Basnayake, J. and Skulkhu, E. 1998. Lowland rice improvement in northern and northeast Thailand. 1. Effects of fertiliser application and irrigation. Field Crops Res, 59, 99-108.

Khush, G.S. 2005. What it will take to feed 5.0 billion rice consumers in 2030. Plant Mol. Biol, 59, 1-6.

Kim, J.-H., Chung, B. Y., Kim, J.-S., Wi, S. G., Yang, D. H., Lee, C.-H. and Lee, 
M-C. 2004. Construction of gene specific primers of various antioxidant isoenzyme genes and their expressions in rice (Oryza sativa L.) seedlings obtained from gammairradiated seeds. J. Photosci, 11, 115-120.

Lu, Z., Liu, D., Liu, S. 2007. Two rice cytosolic ascorbate peroxidases differentially improve salt tolerance in transgenic Arabidopsis. Plant Cell Rep, 26, 19091917.

Menezes-Benavente, L., Teixeira, F.K., Kamei, C.L.A. and MargisPinheiro, M. 2004. Salt stress induces altered expression of genes encoding antioxidant enzymes in seedlings of a Brazilian indica rice (Oryza sativa L.). Plant Sci, 166, 323-33.

Mittler, R., van der Auwerra, S., Gollery, M. and Breusegem, F .V. 2004. Reactive oxygen gene network of plants. Trends Plant Sci, 10, 490-498.

Mittler, R., Zilinskas, B.A. 1994. Regulation of pea cytosolic ascorbate peroxidase and other antioxidant enzymes during the progression of drought stress and following recovery from drought. Plant $J, 5,97-405$.

Morita, S., Kaminaka, H., Masummura, T., Tanaka, K. 1999. Induction of rice cytosolic ascorbate peroxidase mRNA by oxidative stress: the involvement of hydrogen peroxidase in oxidative stress signaling. Plant Cell Physiol, 40, 417-422.

Murgia, I., Tarantino, D., Vannini, C., Bracale, M., Carravieri, S., Soave, C. 2004. Arabidopsis thaliana plants overexpessing thylakoidal ascorbate peroxidase show increased tolerance to Paraquat induced photooxidative stress and to nitric oxideinduced cell death. Plant J. 38, 940-953.

Nguyen, G.N., Hailstones, D.L., Wilkes, M., Sutton, B.G. 2009. Drought-induced oxidative conditions in rice anthers leading to a programmed cell death and pollen abortion. J Agro and Crop Sci, 195, 1-7.

Nguyen, G.N., Sutton, B.G. 2009. Water deficit reduced fertility of young microspores resulting in a decline of viable mature pollen and grain set in rice. J Agro \& Crop Sci, 195, 11-18.

Oh, S.J., Song, S.I., Kim, Y.S., Jang, H.I., Kim, S.Y., Kim. M., Kim, Y.K., Nahm, B.H., Kim, J.K. 2005. Arabidopsis CBF3/ DREB1A and ABF3 in transgenic rice increased tolerance to abiotic stress without stunting growth. Plant Physiol, 138, 341-351.

Prashanth, S., Sadhasivam, R., Parida., V. 2008. A. Over expression of cytosolic copper/zinc superoxide dismutase from a mangrove plant Avicennia marina in indica rice var Pusa Basmati-1 confers abiotic stress tolerance. Transg Res, 17, 281-291.

Sarangi S., Bora, A., Dass., Manda, A.B. 2011. Agrobacterium mediated genetic transformation of indica rice varieties involving Am-SOD gene. Indian J Biotech, 10, 9-18.

Sato, Y., Antonio, B.A., Namiki, N., Takehisa, H., Minami, H., Kamatsuki, K., Sugimoto, K., Shimizu, Y., Hirochika, H., Nagamura, Y. 2011. RiceXPro: A platform for monitoring gene expression in japonica rice grown under natural field conditions. Nucl Acids Res, 39, D1141-D1148.

Sato, Y., Masuta, Y., Saito, K., Murayama, S., Ozawa, K. 2011. Enhanced chilling tolerance at the booting stage in rice by transgenic overexpression of the ascorbate peroxidase gene, OsAPXa. Plant Cell Rep, 30, 399-406.

Scandalios, J.G. 2005. Oxidative stress: molecular perception and transduction of signals triggering antioxidant gene defenses. Braz J Med and Biol Res, 38, 9951014.

Selote, D.S., and Khanna-Chopra, R. 2004. Drought-induced spikelet sterility is associated with an inefficient antioxidant defence in rice panicles. Physiol Plant, 121, 462-471.

Sharoni, A. M., Nuruzzaman, M., Satoh, K., Moumeni. A., Attia, K., Venuprasad, R., Serraj, R., Kumar., A., Leung, H., ul Islam, A. K. M. R., Kikuchi, S. 2012. Comparative transcriptome analysis of AP2/EREBP 
gene family under normal and hormone treatments, and under two drought stresses in NILs setup by Aday Selection and IR64. Mol Genet Genomics, 287, 1-19.

Sinclair, T.R., and Ludlow, M. M. 1986. Influence of soil water supply on the plant water balance of four tropical grain legumes. Aust J Plant Physiol, 13, 329-341.

Sun, W.H., Duan, M., Li, F., Shu, D.F., Yang, S., Meng. Q.W. 2010. Overexpression of tomato tAPX gene in tobacco improves tolerance to high or low temperature stress. Biol. Plant, 54, 614-620.

Tang, L., Kwon, S.Y., Kim, S.H., Kim, J.S., Choi, J.S., Cho, K.Y., Sung, C.K., Kwak, S.S., Lee, H.S. 2006. Enhanced tolerance of transgenic potato plants expressing both superoxide dismutase and ascorbate peroxidase in chloroplasts against oxidative stress and high temperature. Plant Cell Rep, 25, 1380-1386.

Teixeira F K, Menezes-Benavente L, Galvao V C, Margis R, Margis- Pinheiro M. 2006. Rice ascorbate peroxidase gene family encodes functionally diverse isoforms localized in different subcellular compartments. Planta, 224, 300-314.

Tayal, D., Srivastava, P.S. and Bansal, K.C. (2004). Plant Biotechnology and Molecular Markers, First edition, New Dehli: Anamaya Publisher.

Tsai, Y.C., Hong, C.Y., Liu, L.F., Kao, C. H. 2005. Expression of ascorbate peroxidase and glutathione reductase in roots of rice seedlings in response to $\mathrm{NaCl}$ and $\mathrm{H}_{2} \mathrm{O}_{2}$. J. Physiol, 162, 291-299.

Tseng, M.J., Liu, C.W., Yiu, J.C. 2007. Enhanced tolerance to sulfur dioxide and salt stress of transgenic Chinese cabbage plants expressing both superoxide dismutase and catalase in chloroplasts. Plant Physiol. Biochem, 45, 822-833.

Wang, H., Zhang, L., Ma,J., Li, X., Li, Y., Zhang, R. and Wang, R. 2010. Effects of water stress on reactive oxygen species generation and protection system in rice during grain-filling stage. Agri. Sci. China, 9, 633-641.
Wu, G.Q., Zhang, L.N., Wang, Y.Y. 2012. Response of growth and antioxidant enzymes to osmotic stress in two different wheat (Triticum aestivum L.) cultivars seedlings. Plant Soil Environ, 58, 534539.

Xing, Y., Jia, W., and Zhang, J. 2008. AtMKK1 mediated ABA-induced CAT1 expression and $\mathrm{H}_{2} \mathrm{O}_{2}$ production via AtMKK6coupled signaling in Arabidopsis. Plant J, 54, 440-451.

Yamane,K., Mitsuya, S., Taniguch, Mi, and Miyake, H. 2010. Transcription profiles of genes encoding catalase and ascorbate peroxidase in the rice leaf tissues under salinity. Plant Prod. Sci, 13, 164-168.

Yoshimura, K., Yabuta, Y., Ishikawa, T. and Shigeoka, S. 2000. Expression of spinach ascorbate peroxidase isoenymes in response to oxidative stress. Plant Physiol, 123, 223-233.

Yu, H., Chen, X., Hong, Y.Y., Wang, Y., Xu, P., Ke, S.D., Liu, H.Y., Zhu, J.K., Oliver, D.J., Xiang, C-B. 2008. Activated expression of an Arabidopsis HD, START protein conferred drought tolerance with improved root system and reduced stomatal density. Plant Cell, 20, 11341151. 